\title{
NOTES ON THE CONTRADICTIONS OF HOUSING POLICY IN LATIN AMERICA TODAY:
}

\author{
THE SITUATION IN BRAZIL AND VENEZUELA ${ }^{\mathrm{I}}$ \\ Beatriz Tamaso Mioto \\ Pietro Caldeirini Aruto \\ Universidade Estadual de Campinas, Instituto de Economia, \\ Centro de Desenvolvimento Econômico, Campinas, SP, Brasil
}

\begin{abstract}
A B S T R A C T: The production of housing is an important activity for capitalist accumulation and one of the foci of conflict around the appropriation of space. Historically, this required state regulation by various means, including, housing policies. Although it is something present in all socio-spatial formations, the way in which production and regulation of the sector take place in different spaces depends, at bottom, on the ongoing accumulation pattern. Based on this methodological assumption, this article seeks is, in the light of the critical theory of underdevelopment, to analyze the current characteristics and limitations of housing policies in the continent of Latin America. Given the variety of ongoing experiences, the discussion will be centered on the Minha Casa Minha Vida (My House My Life) (Brazil) and Gran Misión Vivienda (Venezuela) programs as being two paradigmatic models of the production of a city. It is said that there are three main differences between these two programs: the subsidy schemes and funding instruments; land policy; and the state's relationship with the fractions of capital that determines the pattern of the policies of the countries.
\end{abstract}

K E Y W O R D S : housing policy; underdevelopment; Brazil; Venezuela.

\section{INTRODUCTION}

The production of housing is an important activity for capitalist accumulation is the ability to extend the circulation and realization of capital, either because the focus on the reproduction of the labor force. Faced with the contradictions and conflicts present in this segment, synthesized by the dispute and production of urban space, state regulation is established by various means, and among them, there are the housing policies. It is through them that it is possible consistency of interests of fractions of capital and the workers. Although housing policies are verified in many of the countries that have achieved a certain degree of development, its size and economic and financial mechanisms are conditioned on the one hand, by the ongoing accumulation pattern and, secondly, the specifics of their own socio-spatial formations (ARUTO, 2015).

Based on this methodological assumption, the general objective of this article is to discuss housing policy, its limits and current characteristics, in under-developed countries in the light of the pattern of accumulation. Faced with the variety of ongo-
1 This article arose out of research conducted by the authors on housing policies in Latin America. Part of it is from the doctoral thesis of one of the authors, and was funded by FAPESP. Among the research activities, attention is drawn to field research having been carried out in Colombia, Mexico and Venezuela. 
2 Although dealt with marginally in this text, another fundamental aspect is the relationship between these agents and the appropriation of public funds, which define the fractions of capital and the working class that really gain from the policies. ing experiences, the discussion will focus on the programs Minha Casa Minha Vida (Brazil) and Gran Misión Vivienda (Venezuela) as being two paradigmatic models of city production: in the former, the strong interplay is stressed of the private economic sectors (developers, construction companies, industry associations, etc.) in decisions about grant mechanisms, financing, implementation and location of projects ${ }^{2}$ in the attempt to combat the housing shortage. As to Venezuela, there is a greater state control over the operation and conduct of works, production of inputs and especially on the location of housing, as well as greater public participation in decision-making.

The article was written based on a theoretical and historical review, which took into account the critical dialogue on issues about housing and economic development. We sought to identify part of the structural determinants of the housing shortage and contemporary factors that aggravate the phenomenon. In addition to constructing this theoretical and historical framework, primary (interviews and field research) and secondary (official data and academic papers) data sources were used, which enabled the most recent manifestations of the problem to be captured, especially the behavior and composition of the housing deficit and some of the results of the policies.

The first section of this paper deals with the general characteristics of the pattern of the reproduction of capital in underdeveloped economies, by seeking to identify the structural "macroeconomic" barriers to housing production in these spaces. The second section shows the general characteristics of $20^{\text {th }}$ century urbanization in the region and the main historical conditions of the overexploitation of labor and the formation of the labor market. This is where the concrete explanation resides for most of the population finding it impossible to have access to formal land and housing markets and, consequently, to their producing the informal city, the shanty towns, the barrios, the ranches, etc. In the third section what are emphasized are the Brazilian and Venezuelan policies, and the two models are contrasted. Finally, some concluding remarks are made about the housing policies in Latin America today.

\section{GENERAL SIGNS OF THE PATTERN OF REPRODUCTION OF CAPITAL IN LATIN AMERICAN ECONOMIES}

The housing problem is not an isolated phenomenon of the entire development. It is the result of a complex combination of structural factors that, in appearance, are placed outside the narrow field of housing and real estate market. Within this whole, economic sectors obey the general laws of accumulation that condition concrete decisions of social classes and the state in the production of space.

In its most abstract conception, the pattern of reproduction of capital (PRC) deals with the way in which the processes of circulating, producing and realizing capital occur. From the point of view of the economy, housing production in capitalist countries concerns the interplay of these "phases" when tackling the following questions: whose decision is it to invest? How much is invested? What is the production relationship like (from the purchase of the workforce, the characteristics of working hours and the concrete reproduction conditions of the labor force)? How are the goods produced consumed? How do States act given the contradictions linked to 
production and/or to the class struggle (regulation of the labor market, social policies, the system of political representation, the distribution of wealth, etc.)?

The answers to these questions are conditioned by the time/ space and scale of analysis. Developed economies base their accumulation process on a structure of high organic composition of capital characterized by the increased production of relative surplus value. In these countries, the increase in the consumption level (value of use mass) of the goods-salaries sector along with the reduction of the value of the workforce played an increasing role in the reproduction of capital cycle, within a backdrop of class conflict. This has, historically, wage levels in real terms permitted comparatively higher salaries, greater homogeneity between the production sectors, and a more comprehensive social policy and/or high capacity to consume goods and public services.

In underdeveloped countries, however, the fluidity of capital in its process of reproduction finds its own material contradictions, confronting which is based on the relationship between external dependence and over-exploitation of the workforce, its internal counterpart. This is defined by the remuneration of the workforce below its value, whether through low wages, whether by increasing the intensity of and the length of the working day (absolute surplus value), namely, by the transformation of part of consumption fund of the worker into an accumulation fund (OSORIO, 2004; MARINI, 2005). This does not mean that there are no correlated forms of exploitation in central capitalism, but it is considered that in these spaces this is an escape route of individual capitalists, while in underdevelopment it is a totalizing category of the movement of reproducing capital.

This dialectic between the internal and external conditions resulted in "imbalances" of various orders such as the segmentation of the labor and consumer market, strong sectoral and regional disparities, the characteristics of the structure of ownership, the "debility" of the national bourgeoisie, etc. The inclusion of the regions into the international division of labor is also conditioned by remaining structures of the colonial period, where the binomial slavery/major land ownership or mining/ encomienda/major land ownership bequeathed a perverse appropriation of land and the formation of a patrimonialist elite.

The active role of economic policy in the reproductive cycle of dependent economies and their industrialization/urbanization should also be emphasized. Historically, it fell to the State to make a significant mass of investments, both in terms of the inability of private capital to concentrate sufficient capital to do so, and to the lack of interest, since other forms of adding value usually linked to a Rentier system (of oil, of the public debt, etc.) and to the dispossession of land and labor prevail.

Through the contradictions described above, which combined industrialization and modernization of the countryside with extremely unequal land tenure, migratory movements resulted in a concentrated urbanization in time and space. Among the various features of this process, those that are of most interest for the housing issue are those related, on the one hand, to the way in which urban land is appropriated and, on the other, how the formation of the labor market occurs and the impossibility of industrializing to absorb the huge contingent that leaves the countryside (MIOTO, 2015).

In the first aspect, rent from the land is one of the fundamental categories used to reach an understanding of the relationship between the economy and the ap- 
propriation of territory in the capitalist mode of production. Theoretically, this was discussed thoroughly by the classical economists and Marx, who showed the importance of what land ownership represents to society not only from the economic point of view but also from the socio-political aspect. Contemporaneously the discussion was relatively abandoned by economists and is more coherent in the works of Harvey (1982). According to him, the classical separation pointed out by Marx between land ownership and its use allows capital to make use of space as a tool and condition of production, thereby turning land into a peculiar commodity. Peculiar because, by means of income, it counts as interest on acquisition money, i.e. as fictitious capital. Thus, the price of land is a mechanism for coordinating the use of land in the economic system.

The land market is in this context determined by the purchase and sale of land, not necessarily as a use value, but rather as a form of appropriation of the income from capitalized land. The price of land is regulated, thus, because of the interest rate and the expectation of future income, both of which are compared with those of the other branches of the economy, thereby demonstrating that the land market is part of the financial market. Financial speculation - linked to future flows of interest, incomes and work - allows the owner to take an active role in the new configurations of production on the land.

Inácio Rangel (RANGEL; SILVA, 2004), already in the 1960s, made an important contribution by treating land as a financial parameter. By analyzing the Brazilian agrarian question - rural and urban - he discusses how, historically in underdevelopment, land became a priced commodity and was converted recurrently into a reserve of value and means of hoarding. He also draws attention to the fact that the perverse formation of the price of land in Brazil is critical to understanding the why of a "behind-the-times" land structure. For him the price of land is a function of income offered by the earth, which in addition to including absolute and differential rents also covers what he called the $4^{\text {th }}$ income. According to him, rising land prices in the country could not be explained by the supply side but by the behavior of demand but not of the demand for land that could be tilled or built on, but by a "speculative" demand. This is linked to the economy because of the existence of an inverse relationship between the price of land and the rate of profit, where the latter oscillates due to the cyclical movement of the economy and the former may have a more "autonomous" cycle. In the known periods of slump and recession of the dependent economies, together with a framework of inflation and persistent instability, the price of land rose, thus also increasing income. Thus, Rangel brought in the specific (speculative and patrimonialist) behavior of the land market and the "uncontrolled" movement of production costs both for the primary sector and for civil construction.

Another fundamental issue is the State's role in this process which was important not only for structuring the land market, but also for the consequence that it brought, i.e. blocking any possibility of agrarian reform (RANGEL; SILVA, 2004). This "flight" from accumulation towards patrimonial gains on land reveal, therefore, the historical relationship mentioned of the underdeveloped elites with the private ownership of land, thus giving a specific character to the land market. Mercantile capital, in this context, has a fundamental role since it represents the most conservative interests of these societies and, although they are metamorphosized over time into more modern faces (of banking, financial, industrial capital, etc.), it persists as 
an engine of speculative operations, which in the words of Lessa (1985), are an "ebbing away" of surpluses including of large capital. This pattern of domination gives the mercantile class extraordinary gains in a double sense: because of the cooptation of the state at local, regional and national levels, whose regulation and directing of investments recurrently alter the levels of appropriation of financialised land rents; and because of the overexploitation of labor.

With regard to the labor market, we maintain that industrialization did not configure an "industrial economy" properly speaking i.e. it did not promote, as in the center of capitalism, an accumulation strongly based on the productivity of labor and the growth of all sectors pf domestic demand. This is due to the fact that to keep the conditions created in the formation of a free labor market by the primary-export sector, overexploitation compressed popular demand. The other side of the stratification of the internal market was the exacerbation of the consumption of the national elites who supported the durable goods of consumption sector and their dynamics of accumulation. Thus, the incorporation of the working masses into the formal labor market was impossible, leading to hypertrophy of the tertiary sector with very low productivity and a tendency for economic growth in many countries to be accompanied by a personal and functional process of the concentration of income.

The urbanization of Latin America, therefore, could not have a result other than it being impossible for much of the population to access the formal land and housing market, even in a framework of strong growth which was what the period between the 1930s and 1970s was. Thus, the development of the cities occurred via a disorderly occupation of lands, generally peripheral ones. These "marginal" spaces, on being incorporated into the urban infrastructure grid, tended to expel the population to the new fringes of expansion of the city.

The production of the underdeveloped city, therefore, gives concrete reality to what we are calling the overexploitation of the workforce, as the reproduction conditions of the labor force are guaranteed by prolonging the working day: for the self-construction of houses; of part of the infrastructure of the communities; and, ultimately, by the excessive dislocation time between the place of residence and work. For no other reason did land reform, housing and transport become central demands of the working class in these countries. To a lesser extent, it was also a matter perceived by the progressive bourgeoisie, who saw that by improving housing conditions and expanding the infrastructure, the possibility arose of decreasing the value of the workforce and increasing the overall productivity of the economy.

Thus, Latin America is developed by means of its own PRC which will condition the class struggle internally and the mediating action of the States vis-à-vis the contradictions indicated. Such patterns can be placed in periods in different ways and have specificities in line with the overall situation of each country, but from the economic point of view, we can point to three main stages: the primary export pattern, until the 1920s; the industrial pattern; and the neoliberal pattern of production specialization that begins in the late 1980s. In the following sections, the history of the common mechanisms of the housing policies of countries will be analyzed, having such reproduction patterns of capital and urbanization as foundations. 


\section{REPRODUCTION PATTERN OF CAPITAL, URBANIZATION AND HOUSING POLICIES IN THE 20 ${ }^{\text {TH }}$ CENTURY}

Latin American countries began a new PRC after the 1929 crisis, boosting, to varying degrees, industrialization through import substitution. Making advances in industrialization was tied to specific political and economic conditions that allowed countries to take an active position vis-à-vis the imbalances triggered by the 1929 crisis (CANO, 2007). Until 1945 what was seen was not only an industrial growth of consumer goods but also the diversification of industrial output in segments of capital goods, where the state compensated for the weaknesses of national capital and the indifference of international capital.

Despite the expansion and diversification of the industrial structure, industrialization was still restricted given the incompleteness of its technical base and its dependence on international bonds provided by the exporting side of the primary sector. Partial overcoming of this limit for some nations would occur from the mid1950s. In many cases, the movement of incorporating the dynamic sectors within the industrial structure occurred when dictatorial governments were formed. The military governments used authoritarian and conservative ways to make industrialization advance but based on strong internal tensions, socio-spatial inequalities and linking to the international flow of capital.

It is appropriate to emphasize that it is more accurate to apply this general schema to those countries in which industrialization advanced the most (Brazil, Mexico and Argentina). Venezuela is a case that deserves to be analyzed in its specificities, as it took shape as an economy based on an oil Rentier system, which would only advance as to industrial diversification in the 1950s. We shall limit the description in the so-called "fiscal and exchange paradox" only to highlight some features for the management of the country's economic and social policy. An eminently export activity like one based on oil has the ability to produce a high tax yield for the state. These incomes, depending on the social and political situation, may to a greater or lesser extent be used towards improving the living standards of the population in general or as an extraordinary source of income of restricted portion of the national elites.

Oil production in countries that are fundamentally structured on this activity tends to generate, at peak times of the activity, an excess of overseas earnings for the country with a corresponding increase in tax revenue and government spending. If this excess of overseas earnings is not somehow sterilized, the impact on the exchange rate will add to the value of the national currency and encourage an increase in imports. In an unfavorable international climate for oil, however, the effects will be the opposite ones, but in a framework that is more difficult to accommodate, since the structure of government spending tends not to be adjustable quickly. In this case, the fiscal imbalance can be great - thus generating a chronic inflationary situation - and the decline in the capacity to import tends to affect adversely the levels of consumption.

This instability also hinders the development of domestic production, as it tends to favor imports to the detriment of the national production structure. Because the oil industry is a sector with a high organic composition of capital, a significant part 
of which is machinery, equipment and supplies for production which are imported, expansion of the sector does not by any means lead to a significant increase in industrial jobs, which makes urbanization coming this movement even more complicated, and social policy in general and housing in particular much more susceptible to the cyclical variations in the economy. Moreover, as the surpluses from oil activity lead to their requiring to finding space for production, from very early on the land and real estate market becomes inaccessible to much of the population (MIOTO, 2015).

Thus, in various contexts, housing policy in Latin America is formed against the background of the contradictions of peripheral industrialization, where the development of productive forces is limited because of the dependent position given the economic system and the national workforce, which will be remunerated at a rate below its value, is in large part prevented from accessing the housing market (MIOTO, 2015). As Cano (2010) puts it, it is mainly from the 1950s, with the acceleration of rural-urban migration and urbanization, that housing becomes a "national problem" and thus the answer via state action starts to be disputed politically. Although the techniques of construction solutions were constrained by the level of development of production forces, the way to face up to the problem will depend on the socio-political forces at work.

Thus, it is clear that the most elaborate proposals (such as those from Cepal) considered that the problem was more complex than the simple manifestation of the quantitative housing deficit, or rather, of the shortage of homes on the market (UTRIA, 1966). This recognition, therefore, articulated the idea that the State was fundamental, on the one hand, if the economic imbalances (providing financing, land, ability to pay - employment, etc.) were to be mitigated and, on the other, to stimulate private sector construction. A third group of agents that will be critical to the housing policy of the period is that of the international organizations and the Alliance for Progress that through the loan terms defined, a priori, the targeting and the level of investment of the programs.

In this context, Brazil and Venezuela, as well as other cases in Latin America, had similar state housing policy initiatives, especially in an institutional framework dated between 1960 and 1980. Under the idea that the construction industry is an important foundation of economic growth and urban development, at that moment, the legal conditions of permanent availability of financial capital to the private sector were consolidated, on a larger scale. Funding came from the "national systems of savings and loans for housing" 3 and from overseas loans.

Through these systems it was possible to raise capital-money in unprecedented amounts and convert it into productive capital - either by funding new ventures, or by the possibility of realizing merchant goods. Moreover, in the specific cases of Brazil and Colombia, the UPC and the UPAC ${ }^{4}$ guaranteed, in a high inflation scenario, the monetary correction of funds, that is, real compensation for funds applied, thus making them more attractive to various types of financial investment competitors. These systems were also linked up with institutions such as the National Housing Bank - Brazil; Banco Nacional de Ahorro y Préstamo - Venezuela; Central Banco Hipotecario - Colombia; and institutes such as the Fondo de Garantia y apoyo a los creditos para vivienda - Mexico who gave technical advice to projects, direct financial support, ensured liquidity and assumed guarantees on behalf of debtors.

This apparatus of organization and funding managed to consolidate different fractions of real estate capital - producer and builder - providing by different routes
3 Sistema Nacional de Ahorro y Préstamo Venezuela - 1961; Sistema Brasileiro de Poupança e Empréstimo - 1964; Corporaciones Privadas de Ahorro y Vivienda Colombia - 1972

4 Standard Unit of Capital (UPC) and Unit of Constant Purchasing Power (UPAC) were parameters that indexed these economies. 
5 Results presented by Pradilla (1987). a considerable mass of financial capital and workers to sustain activity even in periods of recession of national economies. Another important aspect was the merger of finance capital with land ownership, which reduced the barrier to the free movement of capital into the sector. This expansion, from the point of view of the real estate circuit was operated by the local merchant capital that, given the internationalization of the economy, had in this sector a frontier of added value. As Lessa (1985) and Cano (2012) explain, the real estate circuit in metropolises - especially in those which took shape without strong industrial support - was largely responsible for the expansion of employment and urban income and its multiplier effects.

Finally, it is worth noting that the policies had similar results in these countries: the production of the house primarily for the mid-high income strata, thus also generating land with added value and a rise in the price of rents $5^{5}$ This is because: a) the percentage of the population that had access to credit was very small; b) the values added to land arising from the market heating up had an adverse effect on the resources earmarked for new buildings; c) it was politically important to respond to the housing problems of the middle class.

This development policy model is sustained until the mid-1980s, when the structures of state action are being dismantled and transformed with a view to responding to the limitations that the deep economic crises imposed and to the new neoliberal idea that State action should be restricted is directed to economic stability and the construction of an institutional environment that would allow the free mobility of capital. As we will see in the next section, this will also modify the way by means of which housing policy starts to be disputed by the classes and its fractions.

\section{THE CRISIS OF THE PATTERN OF INDUSTRIAL REPRODUCTION, THE RISE OF NEOLIBERALISM AND HOUSING POLICIES IN THE $21^{\text {ST }}$ CENTURY}

The pattern of reproduction of capital inaugurated from the 1980s strongly affected the State's attributions in the development project. The global economic crisis, aggravated by oil shocks (1973 and 1979) and consolidated by the unilateral rise in US interest rates (1979) imposed on peripheral countries an unprecedented adjustment that was reflected in significant changes in the dynamics of accumulation and the political-ideological field. From an economic point of view, this period is marked by the generalization of recessive adjustment policies due to the United States re-taking control of the international private banking system and the fact that international liquidity was placed at the service of US fiscal policy so as to finance its structural deficit. Thus, according to Tavares (2000), the potential of endogenous growth of economies was sterilized and the interests of international finance capital were consolidated. In the ideological field, both the central aspects of neoliberalism as well as the economic policy prescription of the so-called "New Consensus" (materialized in the adherence to the Washington Consensus - 1989) had a still further adverse affect on the fiscal and financial crisis of the State: strong public and private indebtedness, loss of control over the process of inflation and imbalance of public finances.

Latin America was even more affected by this process when, in the 1990s it definitively linked itself to neoliberalism and encouraged the opening of their econ- 
omies for trade and financial transactions, as justification for adopting monetary stabilization programs. The low rate of output growth and the fall in the investment rate were due to maintaining high interest rates, the overvalued exchange rate and a contractionary economic policy, subordinated to the financial logic that requires austerity in public accounts and opening up financial markets.

From the 2000s, despite the maintenance of neoliberalism as a political and economic regime, the countries of the continent had a significant increase in growth when contrasted with the previous two decades, mainly due to two factors: the economic growth of China and the rise in prices of cattle products and energy that gave a boost to primary and extractive export activities; and the rise of progressive governments that implemented social policies (social security, increases in the minimum wage, a credit policy, an employment policy, etc.) and distributive policies focusing on increasing consumption by those on low and meagre incomes.

Even so, the maintenance of the economic policy strengthened the specialization in the export of basic products as the primary instrument to offset the structural deficit in the account of services and the balance of payments, which was a deficit that represents the remuneration of foreign capital coming into Brazil (DELGADO, 2010, p. 114-115).

The neoliberal pattern of capital reproduction changes how underdevelopment is spaced by decentralizing production to adapt to the new demands of capital and decentralizing urban growth which, among other consequences, showed the capacity of the dynamic center of countries had diminished, based on industrial capital, to offer "pull factors" as had happened in previous decades.

The effects of these changes in cities and metropolises led in the 1980s and 1990 s to an acute process of impoverishment, the spatial manifestation of which was peripherization, the socio-spatial segregation and the maintenance or aggravation of the housing problem. The last two factors occur not only by the movement of the poor but also the middle classes and high from the expansion of the real estate sector to the metropolitan peripheries. Another key factor to explain this movement was widespread process of increasing the price of urban land and real estate speculation, which has differentiated access to the city for all income strata (SABATINI, 2006).

In short, the Latin American economy in this new pattern of reproduction is marked by the dominance of financial capital in relation to other fractions of capital, thus making the velocity and revaluation of capital much greater. Urban space, in this process, was a privileged locus of capitalist activity, since real estate business was increasingly associated with speculative gains on land and with large infrastructure and real estate projects (a huge source for extracting value). In underdeveloped countries, where non-capitalist structures specifically work hand-in-hand in the valuation process, national capitals, traditionally linked to civil construction, had to be adapted to the new logic which was even more predatory, from the social and environmental point of view. This resulted in the partial internationalization of companies and in the market capitalization of many of them on the Stock Market, in which adding value to assets was placed as the ultimate goal.

There is no other reason that explains why the most important housing policies of the continent - except in the case of Venezuela - were heavily based on the idea of the subsidy/credit model, in which the State basically acts as a facilitator for the financial market. This model finds support in the prescriptions of international 
bodies such as the Inter-American Development Bank, which have pointed towards solutions to the housing problem of the region from a bias essentially connected to the efficiency of market mechanisms.

\section{Brazilian Housing Policy}

With the extinction of the National Housing Bank (BNH in Portuguese) in 1986 there was a major dismantling of the housing policy in Brazil. Despite some initiatives, the high fiscal austerity which federal entities underwent meant that there were only some specific measures taken. Even when the Statute of the City was ap-

6 Rustic homes: these are those located in buildings in whose construction the following predominate: walls and a roof of wattle, thatch, straw, non-planed timber, container material is used and dirt floors. When the material used in the three components of the structure of the building (wall, roof and floor) are not classified into the same group (durable or rustic) the group that shall be indicated is the one that contains two of the components (IBGE). Surveys of the 1990s (National Household Survey - PNAD - and Census) did not undertake this questioning.

7 Makeshift homes: these are those located in non-residential buildings (shops, factories, etc.), provided they do not have any dependencies intended exclusively for housing purposes (bedroom and kitchen). The following places will also be recorded as makeshift which serve as housing for people although in a transitory way: a building under construction, which serves as housing for labourers on the site; a boat; wagon, railway wagon, etc. tent, stall, cave, bridge, railway station yard, awning of a building, etc. which are serving as shelter at the date of the survey (IBGE).

8 Fundação João Pinheiro (2013).

9 This number may not be exactly comparable to that of 2000 because of methodological changes and, therefore, the increase between 2000 and 2010 should be relativized.

10 MP n. 459, 25/03/2009.

11 As to this, see Fix (2011). proved in 2001 and, consequently, the possibility of applying the social function of Land, the $21^{\text {st }}$ century begins with a backdrop in which social and urban issues had grown much worse. It is no wonder that with few housing programs and a context of rising unemployment and drop in real wages that the housing deficit reached exorbitant levels.

Although there are no homogeneous statistics on which to analyze the evolution of the deficit in the post 1980 period, it can be said that housing conditions worsened. First, the annual decrease of rustic households ${ }^{6}$ between 1980 and 1991 was lower than the growth rate of the urban population - of, respectively, $-2.94 \%$ and $3.06 \%$. Similarly, the annual growth of makeshift homes ${ }^{7}$ in the two decades $(1980 / 1991$ of $5.32 \%$ and $1991 / 2000$ of $6.5 \%)$ far outstrips the growth of the urban population of the same periods $(3.06 \%$ and $2.19 \%)$, thereby reaffirming the impact of the crisis on housing. The factors pointed out therefore outlined the backdrop of the early 2000s, with an urban housing deficit of 5,469,851, corresponding to a percentage of $14.6 \%$ of Brazilian households 8 . The total deficit of Brazil in 2010 was over 6.49 million homes ${ }^{9}$, mainly concentrated in the Southeast and Northeast regions and in the metropolitan regions (Sáo Paulo de Janeiro, Belo Horizonte, Salvador, Recife, Fortaleza and Porto Alegre) and in the population whose income does not exceed three minimum salaries (FJP, 2013).

Within this general situation, the need for a more effective and interlinked policy arises. This was reinforced not only by the hope of a more progressive PT administration contained in the Homes Project (Projeto Moradia) which placed the issue of housing in Lula's first election campaign (2002), but also by the critics who judged the issue within the government (MIOTO, 2015 p.117). According to the same author, this hope did not find material support in the PT government, nor from the economic point of view - given the adoption of recessionary policies of the beginning of the first Lula government and Rousseff's second term - and even less from the political one - since the hegemony of the fractions of capital of construction and real estate capital is practically unchallenged. Thus, as a countercyclical policy vis-à-vis the crisis of 2008 and linked in with the Acceleration of Growth Program, Minha Casa Minha Vida (MCMV in Portuguese) $(2009)^{10}$ comes along to serve primarily anxieties about maintaining the level of employment and investment in real estate, and is subordinated to the macroeconomic policy.

Before the program, the building sector had been putting pressure on the State to improve the institutional and financing conditions, since the opening of the capitals of the largest incorporated into the stock exchange (in the mid-2000s) resulted in the formation of a stock of land they needed to enter the revaluation process ${ }^{11}$. The 
production of new merchandise and expectations of bringing this about in the market was to be guaranteed by inducing various sectors that liaise over the production of homes (inputs, machinery and equipment, finishing, etc.) and on the supply of new families (furniture, appliances, etc.). In December 2013 the Brazilian government had invested 200 billion dollars in the program (of which approximately R \$ 135 billion was in credit via the Caixa Economica Federal bank, and delivered 1.5 million homes with 1.7 million units contracted to the date of completion of this article ${ }^{12}$.

The objective from the point of view of meeting the population's needs is to reduce the housing deficit by building 2 million homes. The program includes rural and urban housing, and the actions of organizations and social movements in drawing up projects. At this point, the discussion will focus on the urban case and on the manner of government funding that favors companies since this is the most important part of the program in terms of amount spent, number of units built and impacts on the production of urban space.

In MCMV, the real estate sector is prompted/ financed to invest in meeting the demand for low-cost housing, mostly the population earning between 0 and 3 minimum wages and up to 10 minimum salaries. It was therefore to be a way out by which the market could be enlisted in a program that targeted a section of the population historically kept way from access to housing. As Arantes and Fix (2009) warn, the investment profile assigned deciding how and where to invest, to the private sector. In the specific case of production for families earning between 0 and 3 minimum wages, despite having the possibility of donating land as a counterpart contribution of the municipality, "production by supply" allows the builder to set the site and the project, and sells the real estate to the Caixa Econômica Federal, which will guarantee, without risks, that it is carried out. Also for the upper bands of the program, funding for individuals guarantees the product will be produced and credit for production and tax relief guarantee production. However, even with these facilities, the delivery of houses for those on very low incomes has encountered problems. According to the Ministry of the Cities, in the first two phases of the program (2009-11/2014), $36.42 \%$ of contracted units of band 1 were delivered, while for the next higher income bracket (between 3 and 5 minimum wages) this proportion was $71.34 \%$.

Thus it is by organizing demand that the units are sold, that is, the projects are formulated outside the reach of the public sector, thus opening breaches that will run counter to the municipal urban development strategy. Moreover, the financing of the infrastructure compatible with the requirements legally established encounter difficulties, since large undertakings take place on more distant and cheaper land. The production of this new infrastructure (via BNDES credit to businesses, for example) or the decrease in the availability of urbanized land tends to increase the price of land. This is because when there is, along with urban sprawl, a compatible extension of infrastructure and urbanized land, the tendency prevails for there to be increases in prices (JARAMILLO, 2006). Therefore, part of the subsidy to purchase the home is transferred to the landowner in the form of income especially in the context of successive increases in the ceiling for house prices and funding. Along similar lines at the time of the $\mathrm{BNH}$ policy, the option to construct new housing estates turned into a field of extensive primitive accumulation field, since "rural" lands now had their incomes appropriated like urban land, which were heavily revalued because of the need for a minimum of infrastructure provided by the State.
12 Data from the accounting statements of the Caixa Econômica Federal. 
As Cardoso, Aragon and Araújo (2011) discuss, the logic of private provision will seek to increase its overall rate of profit in two ways: by reducing to the maximum extent possible production costs and making land cheaper. The first aspect takes place because of economies of scale, (when there are some), technological intensification and, ultimately, by adjusting the remuneration of work. The second occurs because of market gains from the land or even with a change in legislation for the purchase of restricted plots or plots in rural areas. These conditions together imply, in general, a deepening of the periphery and socio-spatial segregation, because the plots themselves for the scale - which are large and cheaper - are rare in areas with infrastructure.

This tendency to land speculation and socio-spatial segregation can be sized in the recent increase in the price of rents - as part of the dynamics of the income from urban land. Graph 1 shows the evolution of the IGP-M (the basis for annual re-adjustments of rent) and the rent price index in Sao Paulo (Secovi) which also considers the re-adjustment on new contracts. The evolution of the data shows a consistent distance between them both from the start of 2009, when the Secovi index increases above that of the IGP-M. Although other research studies are needed to evaluate this movement, it can be said that this dynamic is linked to the revaluation of real estate in general, probably in a different way in accordance with the income bands. As indicated by the data of the deficit, the population which has between 0-3 minimum wages was severely harmed by the market movement and this constitutes a new challenge for housing policy (FJP, 2013).

Comparing the downward rhythm of the deficit $(350,000$ households for the period from 2009 to 2012, i.e. 87,000 households per year) at the rate of units contracted in the same period (approximately 378,000 a year), it is observed that the decrease in the deficit (from a quantitative point of view) shows little correspondence to the increase in contracting units. On the one hand, these data can show some delay in capturing the quantitative results of the program, since it is not necessarily the year of contracting real estate that is the year of delivery and the delivered/ contracted relationship contract is still low.

Graph 1: Evolution of the IGP-M and the rental price index in São Paulo - Secovi, 2004-2014

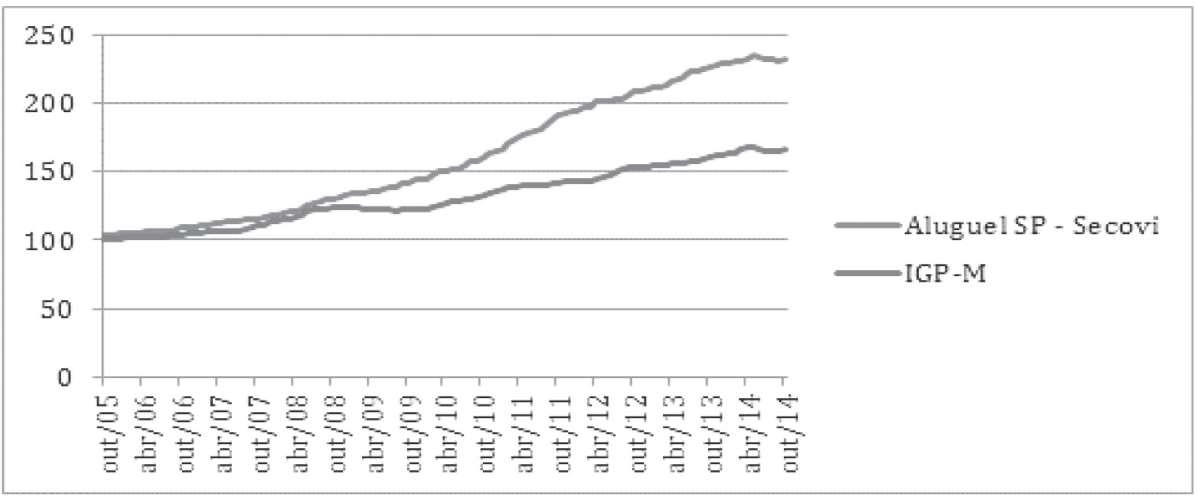

Source: IPEADATA; SECOVI-SP. 
On the other hand, it is believed that part of this result is due to the inability of the policy for resolving the deficit as being a typical manifestation of reproducing underdeveloped urban space. In this sense, coupled to the fact that the pace of migrations decreased in 2000 and that the problem focuses numerically on the metropolises (which have a much lower rate of growth than the national average), the deficit remaining at a time when, historically, the construction of units expanded, suggests that, despite its decline, there is a reproduction of the housing problem.

\section{Housing POLICY in Venezuela ${ }^{13}$}

Venezuela will have a specific trajectory in the 2000s when the economy will reflect the advances and the impasses of a new socio-political project ${ }^{14}$, a more precise analysis of which is beyond the scope of this study. The level of economic growth established in 2004-2008 should be emphasized. This was at an average annual rate of $10.4 \%$ and investment reached an average 34\% share of GDP. More than that, by combining social policy with income transfer and constitutional guarantees at a time of economic growth, workers' condition has improved a lot in the Chavez government: a drop in the inequality of urban income, increased pension coverage and a real minimum wage increase. The social programs adopted by Venezuela should be analyzed beyond the criteria usually adopted for other countries that are more aligned to neoliberal policies. The breadth, nature and participation of the population are subordinated to a socialist-oriented project. Venezuela's housing policy in this period is, therefore, conditioned both by constructing a peculiar state policy project and also by historically erected economic and spatial structures. Venezuela is the country with the highest degree of urbanization in Latin America (93\%).

The urban explosion occurred in the 1950s, caused by the absence of land reform and by attraction to urban areas generated by oil activity. This production specialization, in addition to the economic problems already mentioned, created an urban space that was extremely dependent on the movement of income from oil, since more diversified activities were not developed that would have been to expand urban employment in more stable branches. Thus, the effects that we point out as generators of an extremely uneven urban space, segregated and based on the informality of labor relations and land tenure are deeper in Venezuela.

According to Nuñez (2006, p.17) around 70\% of houses between 1990 and 2001 were built by self-construction processes. Figures from Venezuela's Ministry of Housing point out that in 2006 the housing deficit in the country (quantitative and qualitative) reached 3.9 million families, about $63 \%$ of the Venezuelan population. The recent housing policy is designed in a very different situation from the Brazilian one.

While recognizing the economic and expansion effects of effective demand via increased housing production, the Gran Misión Vivienda arises from the need to serve more than 20 thousand families left homeless in Caracas due to heavy floods in 2010. In addition, the program aims to counterpoint the idea of the city as merchandise or the production of space tied primarily to facilitating the capital appreciation process in the civil construction sectors. The State, with funds generated by oil activity (via PDVSA, the president of which is also the Minister of Housing) funds new units with subsidies for different income strata and controls the conduct of the projects
13 One of the difficulties in analyzing the housing policy in Venezuela is the insufficient availability of official data. The data and analysis contained in this subsection were obtained from interviews and questionnaires made during the August 2013 field research, carried out with funds from FAPESP.

14 For the analysis of Venezuela's economy in the first decade from 2000, see Gonçalves (2009). 
15 José Rafael Nuñez is the Director of Urban Planning of the City Hall of Caracas (carried out by private parties or social organizations) through the Ministry of Housing and the Presidential Office for Special Projects - linked directly to the CEO. The other line of policy is to improve, where possible, existing homes.

The policy differs from MCMV on three key issues: on land policy, on participation of foreign capital and on the relationship with the sectors of the main inputs of construction. As to the land issue, the government (both at the federal and local levels) conducted an inventory in the metropolitan area of Caracas, on property and land use in the Venezuelan capital. On the first point, according to the interview with José Rafael Nuñez ${ }^{15}$, conducting a land inventory revealed a number of processes that characterized the market and the land occupation in the country and specifically in Caracas (which is possibly a feature in common with other Latin American countries if a similar initiative were to be made). The first finding is the fact that the land was being appropriated in extra-economic forms, i.e. many of the lands occupied in central areas and that had a very good infrastructure had no title to the land, and many of those which had, did not show there was compatibility between the documented size of the land and its actual size, which over the years was widening. This trend was noted even in the central regions or those that had a better infrastructure. Not without conflict and with a policy option different from that of other Latin American countries, this was the first line of choice of the land on which to build the new houses, i.e. land which should be under the control of the State.

The second line was the classification of land that can be built on into three groups: those which were not being used (empty areas, the function of which was to have a reserve value - public and private); underused (places where it was possible to increase the "efficiency" of the occupation - building houses, infrastructure, etc.); and the misused, that is, the purpose of which was not compatible with their location (warehouses, parking lots, large warehouses, etc. generally in the city center). This classification enabled the second round of defining the purchase or expropriation of land. This is perhaps the largest difference between the Venezuelan and Brazilian policies because it modifies the mode for controlling the use of urban land, thereby curbing the indirect appropriation of the State's resources by landowners by means of increasing the income from land and inhibiting the expansion of the city into the molds of peripherization.

The second distinction is that, unlike Brazil, in the Venezuelan housing policy, the participation of foreign capital is relevant. This participation is linked to a different production line of the city described above, where the goal is to create new centralities. Thus, there are large housing projects, carried out by foreign companies (Chinese, Russian, Belarusian, Portuguese, Spanish and Brazilian) and that are distant from what are considered the centers of cities. Such undertakings use technology and part of the workforce including foreigners. These projects are bilateral agreements with the goal of making large inversions in foreign exchange credits not necessarily in currency (dollars), but rather, in oil. The estates are in areas that lie further from the city center but they seek to group together a network of services that may avoid the need for large daily movements. Most of the buildings are a mix of residential apartments with small businesses and occupy large sites belonging to the State and one of them, to the army (Ciudad Tiuna). Within the discourse of the government, these are special zones to strengthen a new model of self-government, of a solidarity and sustainable economy (referred to as "large urbanisms"). The share of 
foreign capital in these projects is required on account of the large scale of projects, which could not be undertaken by the State or national companies.

The third specificity is linked to the structural problems of the Venezuelan economy. As already highlighted, production specialization in the country led to restrictions on the diversification of production and in this context supply difficulties of the domestic economy come in. The inputs and construction materials face this problem, unlike Brazil where production is predominantly internal. In this context, for it to be possible to supply the house construction, the Venezuelan State, on the one hand, nationalized part of the production of cement, earthenware and ceramic floors and, on the other, increased the level of imports, concomitantly with the participation of international capital as stated above. The opposition alleges that the monopolization of these sectors would lead to decreased productivity and scarcity in the market, but the fact is that, from then on, the state managed to control and channel the production of inputs for the construction of affordable housing. The state bureaucracy, on the other hand, maintains that the attempts at alliance with these companies when building started was not successful and that, therefore, the nationalization movement was necessary. Obviously this fact goes beyond the objective needs of the housing policy and is a marked feature of the political situation in the country and in the stage of the class struggle. In this model, based on control of land, inputs and projects, housing policy seems to have more coherence with the more accurate planning of the city.

In short, in the model based on the control of land, inputs and projects, housing policy seems to have more coherence with city planning. The field research and the work of Cabrera (2013) show that, although it is not explicit in the formulation of policy, a specific action to combat socio-spatial segregation. There is, in its execution, a relevant practical experience in Latin America, which opens up new paths of discussion. This way of looking at matters should be more prudent for the case of the large urbanisms (which have not yet been finalized), since for its success, it seems to be necessary to mobilize elements that go beyond, to a greater extent, only the construction of the units and their infrastructure. Future studies will enable this experience to be evaluated better.

\section{FINAL REMARKS}

This article has tried to show the close relationship between the needs of capital reproduction in certain historical conditions and housing policies in Latin America. In order to discuss the recent changes in a concrete way, the general characteristics of two important programs in the region were described, and these showed that even with common characteristics, the structure of the projects will depend on the correlation of political forces and how this will reflect in the dispute for the targeting of state policies. This is important because statistically both programs are a success (more than 420,000 houses were built in Venezuela by the end of 2012 and 1.5 million were delivered in Brazil by early 2013), but in terms of solving housing problems for the low-income population, the results seem to be contradictory. As stated in the course of this article, the fundamental difference is in the way in which the land question and the private sector are dealt with. 
In Brazil, the land policy barely follows the housing policy. The reflection of this is not only the spatial segregation (with the creation of closed condominiums and at some distance from the city of more than 4500 units). It is also a tendency of real estate speculation that affects the city as a whole and, in some cases, may increase the housing deficit - especially the one linked to the share of the population which has $30 \%$ or more of household income committed to paying the rent. In a historical situation of over-exploitation of the labor force, this tends to diminish even more employees' funds for consumption, thus worsening the conditions of material life. In Venezuela, despite the absence of statistics, the motion appears to be the opposite. On "spreading" housing through the zones with the best urban infrastructure and mixing the population of the ranchos with the population of middle-income bands, the policy pulverizes the effects of speculation. This is less obvious in the case described on the newly created districts, the effect of which will only be seen in a few yeas' time.

The emphasis on private sector participation in the Brazilian case is fundamental to understanding the design and structuring of the policy. These sectors of the national bourgeoisie (or at least what remains of it) have significant political power in the country due not only to the stock of land and monopoly power they possess, but also because they are the largest funders of political campaigns at all levels of government. For this reason, large developers who run small and medium capital projects (and who usually carry out the works) decided what the general lines of the program would be. Small and medium capital projects, in turn, with regard to improving the characteristics of the labor market (raising the minimum wage and greater formalization of labor relations), continued to have at their disposal, a large mass of workers who still face the worst labor conditions and lower wages compared to other sectors and occupations of the economy. Thus, the policy is making it possible to expand the profit rate of these capital projects, both operationally and financially, by linking these gains to the currents of fictitious capital by opening up capital projects, something that occurred in the mid-2000s, but already shows signs of having dried up (with bad financial results, businesses closing capital on the stock exchange, etc.).

Venezuela has faced several dilemmas regarding the joint policy with the private sector. A detailed understanding of this is beyond the scope of this work, due to the country's situation and the lack of data to support a more rigorous analysis. But some observations ought to be made. First, the control of private capital is substantially lower in Venezuelan politics and was further decreased with the nationalization of some of the input companies. Participation is higher when projects are carried out and these are defined by the government and coordinating entities with strong participation by low-income groups (MIOTO, 2015). What remains open is the re-

Beatriz Tamaso Mioto: bea.mioto@gmail.com.

Pietro Caldeirini Aruto: pietro.aruto@gmail.com.

Article received in March 2015 and accepted for publcation in June 2015. lationship with international private capital, which despite being entered into as a relationship between governments involves large public companies (especially in the Chinese case) and private companies of the country of origin. However, the historical atrophy of the Venezuelan production sector still imposes several restrictions on domestic supply which is exacerbated nowadays by lower oil prices and the economic and political instability in the country. 


\section{REFERENCES}

ARANTES, P.; FIX, M. Como o governo Lula pretende resolver o problema da Habitação: alguns comentários sobre o pacote Minha Casa, Minha Vida. Passa a palavra, 6 ago. 2009. Available at: <http://passapalavra.info/?p=9445>. Accessed on: 19 july 2015.

ARUTO, P. C. A formação socioespacial dependente a partir da superexploração da força de trabalho: uma abordagem metodológica. 2015. 119 f. Thesis (Master's degree in Desenvolvimento Econômico) - Instituto de Economia, Universidade Estadual de Campinas, Campinas, 2015.

CABRERA, B. F. La integración socio-territorial de los sectores populares a la ciudad: un proceso conflictivo. Caso del nuevo urbanismo popular La Limonera. Revista Venezolana de Análisis de Coyuntura, Caracas, v. 19, n. 2, p. 129-157, 2013.

CANO, W. Soberania y politica econômica em América Latina. Havana: Ciencias Sociales, 2007.

Ensaios sobre a crise urbana do Brasil. Campinas: Ed. UNICAMP, 2012.

CARDOSO, A. ARAGÃO, T.; ARAUJO, F. Habitação de Interesse Social: Política ou Mercado? Reflexos sobre a construção do espaço metropolitano. In: ENCONTRO NACIONAL DA ANPUR, 14., 2011, Rio de Janeiro. Anais do XIV Encontro Nacional da Anpur. Rio de Janeiro: ANPUR, 2011. p. 1-20.

PRADILLA, E. Capital, Estado y vivienda en América Latina. México DF: Editorial Fontamara, 1987.

DELGADO, G. Especialização primária como limite ao desenvolvimento. Desenvolvimento em Debate, Rio de Janeiro, v. 1, n. 2, p.111-125, jan./abr. e maio/ago. 2010.

FUNDAÇÃO JOÃO PINHEIRO - FJP. Déficit habitacional municipal no Brasil. Belo Horizonte: Centro de Estatística e Informaçóes, 2013. Available at: <http://www.fjp. mg.gov.br/index.php/docman/cei/deficit-habitacional/216-deficit-habitacional-municipal-no-brasil-2010/file>. Accessed on: 25 jan. 2014.

FIX, M. Financeirização e transformaçóes recentes no circuito imobiliário no Brasil. 2011. $263 \mathrm{f}$. Thesis (Doctorate in Desenvolvimento Econômico) - Instituto de Economia, Universidade Estadual de Campinas, Campinas, 2011.

GONÇALVES, R. Venezuela: rupturas e macrocenários. OIKOS, Rio de Janeiro, v. 8, n. 2, p. 201-221, 2009.

HARVEY, D. The limits to capital. Chicago: University of Chicago press, 1982.

JARAMILLO, S. Reflexiones sobre la informalidad fundiaria como peculiaridad de los mercados del suelo en las ciudades de América Latina. Bogotá: CEDES - Universidad de los Andes, 2006.

LESSA, C. Acumulação Oligárquica e Formação das Metrópoles. Pensamiento Iberoamericano, Madrid, v. 7, p. 214-216, 1985.

MARINI, R. Dialética da Dependência. In: TRASPADINI, R.; STEDILE, J. P. (Org.). Ruy Mauro Marini: Vida e Obra. São Paulo: Expressão Popular, 2005. p. 137-180.

MIOTO, B. T. As politicas habitacionais no subdesenvolvimento: os casos do Brasil, Colômbia, México e Venezuela (1980/2013). 2015. 253 f. Thesis (Doctorate in Desenvolvimento Econômico) - Instituto de Economia, Universidade Estadual de Campinas, Campinas, 2015.

NÚNEZ, J. R. Condiciones precarias de hábitat y vivienda. Caracas: Fundación Escuela de Gerencia Social, 2006.

OSORIO, J. Crítica de la economía vulgar: Reproducción del capital y dependencia. México: Miguel Ángel Porrúa, 2004.

RANGEL, I.; SILVA, J. Questão agraria, industrialização e crise urbana no Brasil. 2. ed. Porto Alegre: Ed. UFRGS, 2004. 
SABATINI, F. La segregación social del espacio en las ciudades de América Latina. Washington: Inter-American Development Bank, 2006.

TAVARES, M. C. Subdesenvolvimento, dominação e luta de classes. In: (Org.). Celso Furtado e o Brasil. São Paulo: Fundação Perseu Abramo, 2000.

UTRIA, R. Los factores estructurales del desarrollo y el problema de la vivienda en América Latina. Boletín Económico de América Latina, 1966.

R E S U M O : A produção de moradias constitui-se em uma importante atividade para a acumulaçáo capitalista e em um dos focos de conflito ao redor da apropriação do espaço. Isso exigiu, historicamente, a regulação estatal por diversos meios, entre eles, as políticas habitacionais. Ainda que seja algo presente em todas as formaçôes socioespaciais, a maneira pela qual se dá a produção e a regulação do setor nos diferentes espaços depende fundamentalmente do padrão de acumulação em curso. Com base nesse pressuposto metodológico, o objetivo do trabalho é, à luz da teoria crítica do subdesenvolvimento, analisar as atuais características e limites das politicas habitacionais no continente latino-americano. Diante da variedade de experiências em curso, a discussáo será centrada nos programas Minha Casa Minha Vida (Brasil) e Gran Misión Vivienda (Venezuela) enquanto dois modelos paradigmáticos da produção da cidade. Constata-se que três são as principais diferenças entre esses dois programas: os esquemas de subsidios e instrumentos de financiamento; a política fundiária; e a relação do Estado com as fraçóes de capital que determina o padrão das políticas dos países.

P A L A V R A S - C H A V E : politica habitacional; subdesenvolvimento; Brasil; Venezuela. 